\title{
PERENCANAAN SISTEM DRAINASE JALAN RAYA (STUDI KASUS JALAN ARIA WIRATANUDATAR CIANJUR)
}

\author{
${ }^{1}$ Eri Rihandiar, ${ }^{2}$ Muhammad Dikriyanto \\ Program Studi Teknik Sipil Fakultas Teknik Universitas Suryakancana \\ eri.rihandiar@yahoo.co.id
}

\begin{abstract}
Abstrak
Banjir merupakan masalah yang mengganggu kelancarana aktivitas suatu kawasan. Oleh sebab itu diperlukan penanganan drainase secara tetap dan efisien pada kawasan tersebut, yang akan berdampak pada naiknya produktivitas ekonomi di kawasan yang terkena banjir.

Ada beberapa kawasan di Kabupaten Cianjur yang merupakan daerah rawan banjir, salah satunya di ruas Jalan Aria Wiratanudatar Kab. Cianjur, daerah tersebut mengalami banjir apabila diguyur hujan sehingga air dari saluran drainase melimpas ke perkerasan jalan. Menurut hasil survei, banjir tersebut dialami karena faktor penyempitan dimensi saluran drainase, penyumbatan saluran, jadi saluran yang ada pun tidak mampu mengalirkan debit air dengan secepatnya ke pembuangan akhir. Maka dari itu tujuan penelitian ini akan merencanakan kembali dimensi saluran drainase dengan data curah hujan yang ada atau didapat dari instansi terkait, penelitian ini dimulai dari survei lapangan kemudian pengumpulan data dan pengolahan data sampai dengan perhitungan dimensi saluran baru dan merencakan sumur resapan sebagai alternatif lain daripada drainase.

Lokasi yang ditinjau sepanjang 3,2 km, metode yang digunakan dalam penelitian ini untuk mencari intensitas curah hujan (I) yaitu distribusi Gumbel, dan untuk menghitung besarnya debit pengaliran (Q) menggunakan metode Rasional, dari hasil analisa yang dilakukan, saluran drainase pada lokasi yang ditinjau ruas jalan Aria Wiaratnudatar Kab. Cianjur yang dibagi menjadi 3 (tiga) bagian P1,P2, dan P3, melalui pengamatan dan penelitian perhitungan, Besarnya debit limpasan air yang mengalir dilokasi yang ditinjau dengan hasil perhitungan yaitu: $P 1=1,27 \mathrm{~m}^{3} /$ detik, $P 2=1,17 \mathrm{~m}^{3} /$ detik, $P 3=1,37 \mathrm{~m}^{3} /$ detik.

Kata Kunci : Saluran Drainase, Debit air, banjir, Data curah hujan, dan Sumur Resapan.
\end{abstract}

\section{PENDAHUluan}

Dengan semakin pesatnya pertumbuhan penduduk, sumber daya air di dunia telah menjadi salah satu kebutuhan yang sangat penting. Air merupakan hal yang pokok bagi konsumsi dan sanitasi umat manusia. Air dapat digunakan untuk produksi berbagai bahan industri. Selain itu air juga merupakan sumber tenaga, sarana pengangkutan dan alat transportasi yang mempunyai fungsi penting di berbagai belahan dunia. Sumber daya yang berharga sekalipun dapat pula menjadi bahaya. Demikian pula halnya dengan air yang berlebihan. Jumlah air hujan atau bentuk presipitasi lainnya yang berlebihan dapat mengakibatkan banjir sehingga dapat menimbulkan bahaya kerusakan berat dan korban jiwa yang banyak jumlahnya.

Sumber daya air di bumi ini harus dikelola dengan tepat agar dapat memenuhi kebutuhan manusia dan juga agar tidak menimbulkan kerugian-kerugian. Pengelolaan yang tepat sangat dibutuhkan agar kebutuhan air untuk berbagai kebutuhan di bumi ini dapat terpenuhi dengan baik. Dengan perencanaan yang baik, jumlah air berlebih dari sisa presipitasi dapat diperhitungkan sehingga tidak menimbulkan limpasan berlebihan yang dapat menimbulkan banjir di permukaan.

Maka dari itu perlu diperhatikannya fasilitas penunjang pengairan, agar limpasan air yang berlebihan dapat diminimalisasi contoh fasilitasnya yaitu saluran drainase, saluran drainase adalah salah satu bangunan pelengkap pada ruas jalan dalam memenuhi salah satu persyaratan teknis prasarana jalan.

Saluran drainase jalan raya, perumahan, pabrik, taman kota dan lain sebagainya berfungsi untuk mengalirkan air akibat hujan yang dapat mengganggu aktivitas, sehingga permukaan di wilayah tersebut tetap kering dan tidak menimbulkan genangan. Pada umumnya saluran drainase adalah saluran terbuka dengan menggunakan gaya gravitasi untuk mengalirkan air menuju outlet. Distribusi aliran dalam saluran drainase ini mengikuti kontur tanah, sehingga air permukaan akan lebih mudah mengalir secara gravitasi. 
Dalam perencanaan saluran drainase harus memperhatikan tata guna lahan daerah tangkapan air saluran drainase yang bertujuan menjaga ruas jalan tetap kering dan tidak menyebabkan banjir walaupun terjadi kelebihan air, sehingga air permukaan tetap terkontrol dan tidak mengganggu pengguna jalan.

Pengembangan pembangunan jalan di kota Cianjur yang cukup pesat akan mengurangi area resapan air hujan di sepanjang ruas jalan apabila sistem drainase tidak diterapkan dengan baik dan dapat menimbulkan genangan-genangan nantinya. Buruknya kondisi saluran drainase di JL. Aria Wiratanudatar Cianjur menjadi permasalahan sosial dan kenyamanan pengendara kendaraan saat melintas di jalan tersebut pada kondisi hujan, selain itu saluran drainase yang telah adapun tidak berfungsi sebagaimana mestinya dan tidak dapat menampung dan mengalirkan air apabila hujan deras turun di daerah tersebut, hal tersebut berakibatkan air meluap ke ruas jalan disertai sampah-sampah yang ikut naik ke permukaan jalan, maka dari itu sistem drainase harus diperhatikan kembali agar tetap mampu mengalirkan air akibat dari hujan deras dan fungsi efisiensinya tetap ada.

Penataan dan peningkatan efisiensi sistem drainase di J1. Aria Wiratanudatar Cianjur perlu segera dilakukan agar permasalahan banjir dan genangan serta segala akibat yang timbul karenanya dapat diantisipasi. Sebab permasalahan tersebut menimbulkan banyak gangguan pada masyarakat terutama kenyamanan berkendara saat hujan deras. Tujuan dari penelitian ini untuk merencanakan debit limpasan yang terjadi di JL. Aria Wiratanudatar dan sekitarnya yang akan membebani saluran drainase jalan. Menganalisa kondisi saluran drainase eksistingnya., merencanakan saluran drainase JL. Aria Wiratanudatar, Membuat perencanaan detail penampang saluran pada jalan, dan mengurangi genangan air pada perkerasan jalan.

\section{TINJAUAN PUSTAKA}

Drainase atau drainage yang mempunyai arti mengalirkan, menguras, membuang, atau mengalihkan air. Dalam bidang teknik sipil, drainase secara umum dapat didefinisikan sebagai suatu tindakan teknis untuk mengurangi kelebihan air, baik yang berasal dari air hujan, rembesan, maupun kelebihan air irigasi dari suatu kawasan atau lahan, sehingga fungsi kawasan atau lahan tidak terganggu, dengan tujuan akhir untuk mengembalikan ataupun meningkatkan fungsi kawasan. Definisi lain sistem drainase merupakan suatu rangkaian bangunan air yang berfungsi mengurangi dan atau membuang kelebihan air dari suatu kawasan.

Jika diasumsikan besarnya curah hujan dan intensitas hujan selalu tetap maka limpasan yang dinyatakan dengan dalamnya air rata-rata akan selalu sama. Berdasarkan asumsi tersebut mengingat aliran per satuan luas tetap maka ketinggian aliran sungai akan sebanding dengan luas daerah pengaliran tersebut.

Sesuai dengan prinsip sebagai jalur pembuangan maka pada waktu hujan, air yang mengalir di permukaan diusahakan secepatnya dibuang agar tidak menimbulkan genangan yang dapat mengganggu aktivitas dan bahkan dapat menimbulkan kerugian (R. J. Kodoatie, 2005).

Sumber penyebab utama permasalahan drainase adalah peningkatan pertumbuhan jumlah penduduk. Urbanisasi yang terjadi di hampir seluruh kota besar di Indonesia akhir-akhir ini menambah beban daerah perkotaan menjadi lebih berat. Peningkatan jumlah penduduk selalu diikuti dengan peningkatan infrastruktur perkotaan seperti perumahan, sarana transportasi, air bersih, prasarana pendidikan, dan lain-lain. Di samping itu peningkatan penduduk selalu juga diikuti dengan peningkatan limbah, baik limbah cair maupun padat (sampah). Kebutuhan akan lahan untuk permukiman maupun kegiatan perekonomian akan semakin meningkat sehingga terjadi perubahan tataguna lahan yang mengakibatkan peningkatan aliran permukaan dan debit puncak banjir.

Menurut konsepnya, sistem jaringan drainase dibedakan menjadi 2, yaitu:

1. Drainase konvensional

Drainase konvensional adalah upaya membuang atau mengalirkan air kelebihan secepatnya ke sungai terdekat. Dalam konsep drainase konvensional, seluruh air hujan yang jatuh di suatu wilayah harus secepatnya dibuang ke sungai dan seterusnya mengalir ke laut. Jika hal ini dilakukan pada semua kawasan, akan memunculkan berbagai masalah, baik di daerah hulu, tengah, maupun hilir. Dampak dari pemakaian konsep drainase konvensional tersebut dapat kita lihat sekarang ini, yaitu kekeringan yang terjadi di manamana, juga banjir, longsor, dan pelumpuran. Kesalahan konsep drainase konvensional yang paling pokok adalah filosofi membuang air genangan secepatnya ke sungai. Demikian juga mengalirkan air secepatnya berarti menurunkan kesempatan bagi air untuk meresap ke dalam tanah. Dengan demikian, cadangan air tanah 
akan berkurang kekeringan di musim kemarau akan terjadi. Sehingga banjir dan kekeringan merupakan dua fenomena yang saling memperparah dan terjadi susul-menyusul.

2. Drainase Ramah Lingkungan

Drainase ramah lingkungan didefinisikan sebagai upaya mengelola air kelebihan dengan cara sebanyak-banyaknya meresapkan air ke dalam tanah secara alamiah atau mengalirkan ke sungai dengan tanpa melampaui kapasitas sungai sebelumnya. Dalam drainase ramah lingkungan, justru air kelebihan pada musim hujan harus dikelola sedemikian rupa sehingga tidak mengalir secepatnya ke sungai, namun diusahakan meresap ke dalam tanah, guna meningkatkan kandungan air tanah untuk cadangan pada musim kemarau.

Beberapa metode drainase ramah lingkungan yang dapat dipakai diantaranya adalah metode kolam konservasi, metode sumur resapan, metode river side polder, dan metode pengembangan areal perlindungan air tanah.

\section{METODOLOGI PENELITIAN}

Penulisan laporan Tugas Akhir ini memerlukan adanya suatu metode atau cara yaitu tahapantahapan dalam memulai penulisan sampai selesai, sehingga penulisan Tugas Akhir ini sesuai dengan jadwal dan diperoleh cara analisa sistem drainase di kota Cianjur. Adapun data pendukung yang diperlukan dalam merencanakan sistem drainase di JL. Aria Wiratanudatar Cianjur ini adalah berupa data primer dan data sekunder, yang akan dianalisis dan diperhitungkan.

Tahap persiapan perlu dilakukan karena membantu dalam menentukan hal- hal yang dibutuhkan pada tahapan-tahapan selanjutnya. Tahap persiapan meliputi kegiatan sebagai berikut :

1. Menentukan kebutuhan data;

2. Studi pustaka terhadap landasan teori yang berkaitan dengan penanganan permasalahan untuk menentukan garis besarnya;

3. Menentukan instansi - instansi terkait yang dapat dijadikan narasumber data;

4. Survey lokasi untuk mendapatkan gambaran umum kondisi wilayah;

\section{a. Gambaran Umum Wilayah Studi}

Pelaksanaan evaluasi terhadap sistem drainase jalan Aria Wiratanudatar Cianjur kota dapat dilakukan melalui 3 (tiga) proses tahapan, yakni terdiri dari :

1. Melakukan survei lapangan pada saat terjadinya hujan yang deras, serta mengamati dan mengidentifikasi sumber-sumber penyebab terjadinya banjir dan genangan air permukaan, baik ditinjau pada bangunan drainase yang ada maupun lingkungan disekitarnya.

2. Melakukan survei pada saat kondisi normal dan melakukan pencatatan data kondisi penampang drainase serta dengan permasalahan yang terjadi saat survei.

3. Mengumpulkan sejumlah data-data sekunder anatara lain Data Curah Hujan dari setasiun pengamatan terdekat dan memperoleh peta Topografi, dengan mengkoordinasi instansi terkait baik itu PSDA-P kota Cianjur dan Badan Koordinasi Survei dan Pemetaan Nasional(BAKOSURTANAL/GEOSPASIAL) Cibinong-Bogor.

Dari hasil survei dilapangan saat hujan deras terjadi, air dari saluran drainase yang ada baik itu drainase alamiah maupun drainase yang sudah terbangun atau terstruktur, peluapan air akan terjadi dan menggenangi ruas jalan.

Disamping itu limpasan air masuk ke pekarangan rumah warga yang ada di sekitar ruas jalan bahkan masuk kedalam rumah warga, dan kondisinya sangat memperihatinkan dimana hampir pada tiap musim hujan terutama dengan itensitas yang tinggi air permukaan mengalir dengan deras dan menggenangi ruas jalan hal tersebut menganggu pengendara yang melintasi jalan. Pada saat survey dilakukan ketinggian air limpasan yang melintasi ruas jalan kurang lebih $15 \mathrm{~cm}$.

Sedangkan pada musim kering drainase yang ada seakan terlihat normal, namun pada saat kerig terlihat ruas jalan berlubang dan sampah - sampah yang ada disaluran drainase tertahan di ruas jalan. Dari hasil identifikasi dilapangan, di peroleh beberapa hal yang menjadi penyebab besarnya limpasan air permukaan yang meluap ke ruas jalan, antara lain :

1. Berkurangnya kapasitas pengaliran atau penyempitan luas penampang drainase jalan akibat sedimentasi lumpur, sampah.

2. Adanya bangunan utilitas seperti instalasi listrik jaringan pipa, PDAM dan jaringan telekomunikasi di sepanjang saluran sehingga terjadi penyumbatan saluran drainase akibat sampah dan endapan lumpur yang menganggu proses pengaliran.

\section{b. Data Existing Saluran Drainase Jl. Aria Wiratanudatar}

- Data Teknis Saluran Drainase

Panjang ruas atau saluran $=3200 \mathrm{~m}$

Lebar perkerasan jalan $=5,0 \mathrm{~m}$

Lebar bahu jalan $=1,0 \mathrm{~m}$ (masing-masing 
$0,5 \mathrm{~m})$.

Kemiringan perkerasan $=2,00 \%$

Kondisi permukaan jalan $=$ Sedang

Bentuk saluran yang ada $=$ Persegi empat

Kontruksi $=$ Pasangan batu belah dan alami

Dimensi saluran yang ada $=70 \times 20 \mathrm{~cm}$

Lebar daerah pengaliran $\quad=50+50+6$

$=106 / 2=53+0,70$ (lebar existing)

$=53,7 \times 3200$ (Panjang ruas atau saluran)

$=171.840 \mathrm{~m} 2$

\section{c. Data Curah Hujan}

Sebagai dasar penelitian dalam mengevaluasi saluran Drainase jalan Aria Wiratanudatar adalah membandingkan antara data-data kondisi existing yang diperoleh melalui survei lapangan dengan besaran curah hujan yang turun dikawasan lokasi penelitian, sehingga dapat diketahui besarnya debit pengaliran air permukaan, data curah hujan yang diperoleh dari Dinas Pengolahan Sumber Daya Air dan Pertambangan (PSDA-P) kota Cianjur, stasiun yang terdekat dengan lokasi penelitian yakni Sta Cianjur Kota dengan periode ulang (n) 10 tahun, mulai dari tahun 2004 sampai dengan 2013. Dari data yang diperoleh tersebut dapat diketahui meningkatnya intensitas curah hujan maksimum rata-rata pertahun, data curah hujan terlampir pada tabel 3.2 berikut :

Tabel 3.1 Data Curah Hujan Harian Maksimum Rata-rata Pertahun.

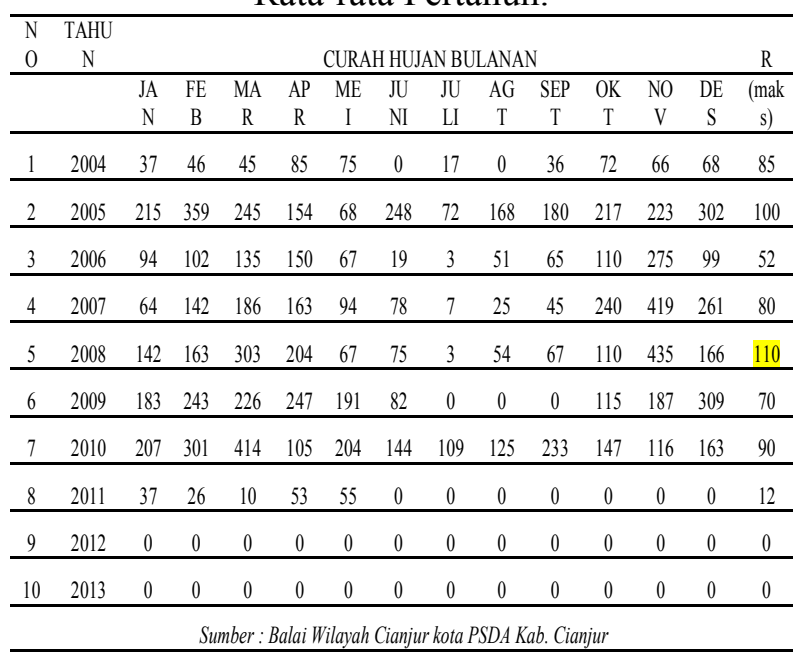

\section{ANALISIS DATA}

Disepanjang lokasi yang ditinjau terdapat Tiga (3) anak sungai yang menjadi pembuangan limpasan air, maka sepanjang $3200 \mathrm{~m}$ perhitungan akan dibagi tiga (3) ruas jalan untuk menentukan dimensi saluran dengan batas tiap-tiap pembuangan (outlet), yakni P1, P2, dan P3.

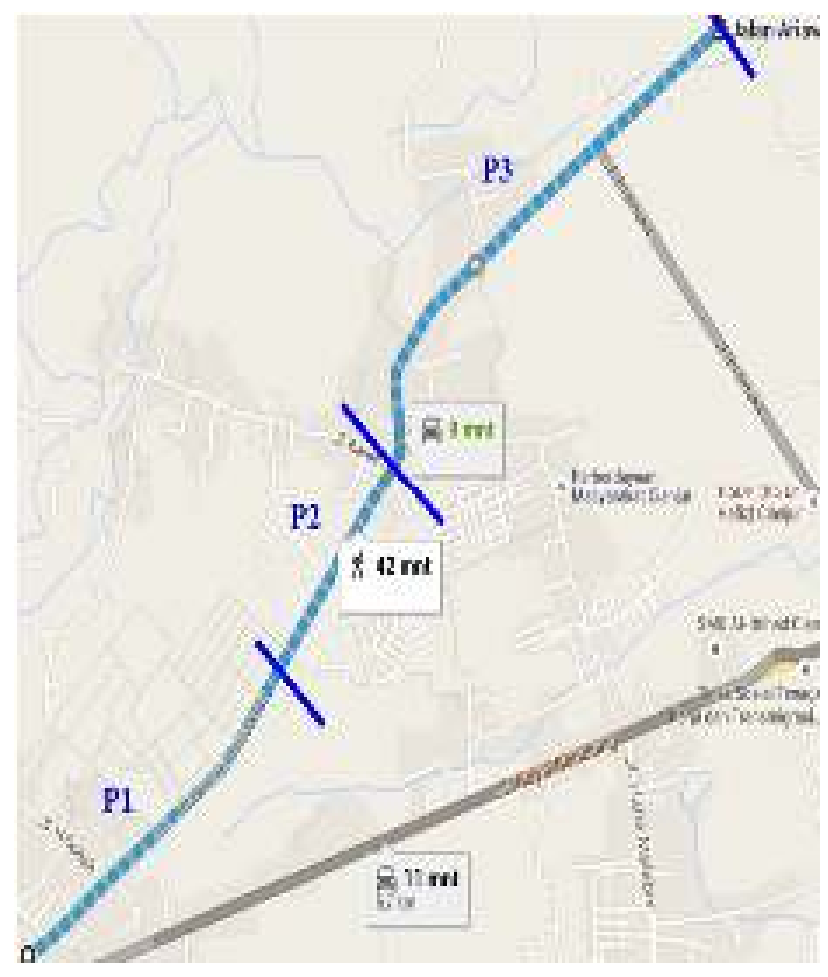

Gambar 4.1. Panjang Saluran Limpasan Air P1 $=$ $1066 \mathrm{~m}, \mathrm{P} 2=950 \mathrm{~m}, \mathrm{P} 3=1184 \mathrm{~m}$

\section{a. Periode Ulang (T) Tahun}

Untuk menentukan Intensitas curah hujan pada penelitian saluran drainase ditentukan periode ulang 5 tahun dengan jumlah data (n) 10 tahun dan variasi Yт sebagai fungsi periode ulang, terlampir pada tabel 4.1, 4.2, dan 4.3 berikut:

Tabel 4.1 Nilai Yt sebagai fungsi periode ulang.

\begin{tabular}{cc}
\hline $\begin{array}{c}\text { Periode Ulang } \\
\text { (Tahun) }\end{array}$ & Yt \\
\hline 2 & 0,3665 \\
\hline 5 & 1,4999 \\
\hline 10 & 2,2502 \\
\hline 25 & 3,1985 \\
\hline 50 & 3,9019 \\
\hline 100 & 4,6001 \\
\hline
\end{tabular}

Sumber : Tata cara Perencanaan Drainase Permukaan Jalan SNI-03-3424-1994 
Tabel 4.2 Nilai Yn sebagai standar Deviasi.

\begin{tabular}{|c|c|c|c|c|c|c|c|}
\hline & 0 & 1 & 2 & 3 & 4 & & $\begin{array}{l}\text { Menghitung rata-rata Aritmatik hujan kumulatif } \\
\text { dapat dihitung menggunakan rumus statistik berikut }\end{array}$ \\
\hline 10 & 0,4952 & 0,4996 & 0,5035 & 0,507 & 0,51 & 0,5128 & Deviasinya, maka nilai rata-rata kumulatif adalah : \\
\hline 20 & 0,5225 & 0,5225 & 0,5268 & 0,5283 & 0,5296 & 0,5309 & \\
\hline 30 & 0,5362 & 0,5371 & 0,538 & 0,5388 & 0,5402 & 0,5402 & $\overline{10}$ \\
\hline 40 & 0,5436 & 0,5422 & 0,5448 & 0,5453 & 0,5458 & 0,5463 & \\
\hline 50 & 0,5485 & 0,5489 & 0,5493 & 0,5497 & 0,5501 & 0,5504 & \\
\hline
\end{tabular}

Sumber : Tata cara Perencanaan Drainase

Permukaan Jalan SNI-03-3424-1994

Tabel 4.3 Nilai Sn.

\begin{tabular}{|c|c|c|c|c|c|c|c|}
\hline $\mathrm{N}$ & 0 & 1 & 2 & 3 & 4 & 5 & 10 \\
\hline 10 & 0,9496 & 0,9676 & 0,9833 & 0,9971 & 1,0095 & 1,0206 & $\mathbf{X}_{\mathbf{T}}=\mathbf{X}+\frac{s x}{s_{n}} \times\left(\mathbf{Y}_{\mathbf{T}}-\mathbf{Y} \mathbf{n}\right)$ \\
\hline 20 & 0,0628 & 1,0696 & 1,0696 & 1,0811 & 1,0864 & 1,0915 & $-\mathbf{X}_{\mathbf{T}}=77+\frac{31,75}{1.4999-0.5128)} \times(1)$ \\
\hline 30 & 0,1124 & 1,1159 & 1,1159 & 1,1226 & 1,1255 & 1,1285 & $10770 \frac{1,0206}{1,24 i}$ \\
\hline 40 & 0,1413 & 1,1436 & 1,1436 & 1,148 & 1,1499 & 1,1519 & $101, / 0 \mathrm{n}$ \\
\hline
\end{tabular}

\begin{tabular}{lllllll}
50 & 0,1607 & 1,1623 & 1,1623 & 1,1658 & 1,1667 & 1,1681 \\
\hline
\end{tabular} Sumber : Tata cara Perencanaan Drainase Permukaan Jalan SNI-03-3424-1994

Nilai Yт Sebagai fungsi periode ulang 5 tahun

- Dari Tabel 4.1 (Yт) 1,4999

- Dari Tabel 4.2(Yn) 0,5128

- Dari Tabel 4.3 (Sn) 1,0206

b. Perhitungan Intensitas Curah Hujan

Menentukan Intensitas curah hujan (I) digunakan analisa distribusi Gumbel, dari data curah hujan yang didapat kemudian dihitung sebagai berikut :

Tabel 4.4 Perhitungan Data Curah Hujan.

\begin{tabular}{|c|c|c|c|}
\hline Tahun & $\begin{array}{l}\text { Hujan Harian } \\
\text { Maksimum } \\
\text { (mm) Xi }\end{array}$ & $\begin{array}{c}\text { Deviasi } \\
\text { Xi-X }\end{array}$ & $(\mathrm{Xi}-\mathrm{X})^{2}$ \\
\hline 2012 & 116 & 39 & 1521 \\
\hline 2008 & 110 & 33 & 1089 \\
\hline 2005 & 100 & 23 & 529 \\
\hline 2010 & 90 & 13 & 169 \\
\hline 2004 & 85 & 8 & 64 \\
\hline 2007 & 80 & 3 & 9 \\
\hline 2009 & 70 & -7 & 49 \\
\hline 2011 & 67 & -10 & 100 \\
\hline 2006 & 52 & -25 & 625 \\
\hline 2013 & 0 & -77 & 5929 \\
\hline $\begin{array}{c}n= \\
10\end{array}$ & 770 & \multicolumn{2}{|c|}{$\sum(\mathrm{Xi}-\mathrm{X})^{2}=10084$} \\
\hline$X=$ & 77 & & \\
\hline
\end{tabular}

$\mathrm{Sx}=\sqrt{\frac{(\mathrm{Xi}-\mathrm{X})^{2}}{n}}=\sqrt{\frac{\mathbf{1 0 0 8 4}}{\mathbf{1 0}}}=31,75$

Maka besarnya curah hujan dengan periode ulang 5 dalam $(\mathrm{mm} / \mathrm{jam})$, metode yang dilakukan untuk mencari Intensitas curah hujan didasarkan rumus Van Breen, persamaan tersbut adalah :

$\mathrm{I}=\frac{90 \% \mathrm{XT}_{\mathrm{T}}}{4}=\frac{90 \% X 107,70}{4}=24,23 \mathrm{~mm} / \mathrm{jam}$

Dengan :

$\mathrm{I}=$ Intensitas curah hujan $\mathrm{mm} / \mathrm{jam}$

$\mathrm{XT}_{\mathrm{T}}=$ Curah hujan periode ulang 5 tahun $\mathrm{mm} / 24 \mathrm{jam}$

c. Kurva Basis

Harga Inensitas curah hujan (I) diketahui $\mathrm{I}=24,23$, diperoleh pada waktu intensitas $\mathrm{t}=240$ menit (dari kurva basis), tarik garis lengkung searah dengan garis lengkung kurva basis, maka garis yang ditarik tersebut adalah garis lengkung intensitas curah hujan rencana.

\section{d. Data Kemiringan Lapangan}

Kemiringan lapangan ditentukan berdasarkan peta Topografi, dikarenakan tidak memperoleh alat untuk menentukan kemiringian tanah seperti waterpass dan klinometer.

Menurut peta Topografi diperoleh nilai beda tinggi yaitu :

- $\quad$ Panjang ruas $=3200 \mathrm{~m}$ '

- $\mathrm{t} 1=390 \quad \mathrm{~m}$ '

- $\mathrm{t} 2=345 \quad \mathrm{~m}$ '

- $\mathrm{t} 1-\mathrm{t} 2=390-345=45 \mathrm{~m}^{\prime}$ 


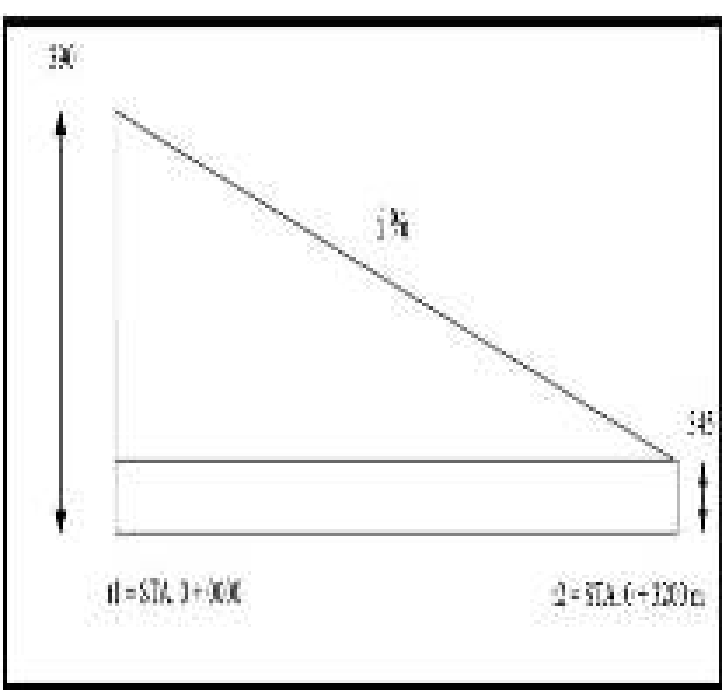

Gambar 4.1 : Kemiringan Lapangan Ruas Jalan Aria Wiratanudatar Sumber : Penyusun

\section{e. Analisa Perhitungan Drainase}

\section{Existing Saluran Drainase P1}

Panjang daerah pengaliran ditentukan sesuai dengan panjang ruas jalan, dikarenakan dimana secara keseluruhan pengaliran air permukaan dari kawasan tersebut mengalir dan melimpas di atas perkerasan jalan.

Daerah Pengaliran P1

- Panjang saluran drainase 1066

$\mathrm{m}$

- $\mathrm{L} 1=$ perkerasan jalan $2,5 \mathrm{~m}$

- $\mathrm{L} 2=$ bahu jalan $0,5 \mathrm{~m}$

- $\mathrm{L} 3$ = bagian luar jalan $50 \mathrm{~m}$

Keterangan :

L3 Bagian luar jalan $=50 \mathrm{~m}$, berdasarkan tata cara perencanaan drainase SNI-03-3424-1994.

\section{Waktu Konsentrasi}

Waktu terpendek dibutuhkan untuk daerah tangkapan air dalam menyalurkan aliran secara simultan (run off ), setelah melewati titik-titik tertentu untuk menentukan waktu konsentrasi (Tc ) digunakan rumus sebagai berikut :

$$
\begin{aligned}
& \mathrm{Tc}=\mathrm{t} 1+\mathrm{t} 2 \\
& \mathrm{t} 1=\left(2 / 3 \times 3,28 \text { Lo } \times \mathrm{nd} / \sqrt{ }_{\mathrm{s}}\right) \\
& \mathrm{t} 2=\mathrm{L} / 60 \times \mathrm{V}
\end{aligned}
$$

Keterangan :

$\mathrm{Tc}=$ Waktu konsentrasi (menit)

$\mathrm{t} 1=$ Waktu intlet (menit)

t2 $=$ Waktu aliran (menit)

Lo $=$ Jarak dari titik ke fasilitas drainase $(\mathrm{m})$

nd $=$ Koefisien hambatan

$\mathrm{s}=$ Kemiringan daerah pengaliran

$\mathrm{V}=$ Kecepatan rata-rata di saluran $(\mathrm{m} / \mathrm{dt})$

$\mathrm{L}=$ Panjang saluran $(\mathrm{m})$
Tabel 4.5 Hubungan Kondisi Pemukiman dengan Koefisien Hambatan.

\begin{tabular}{lc}
\hline \multicolumn{1}{c}{ Kondisi Lapis Permukaan } & $\mathrm{Nd}$ \\
\hline 1. Lapisan semen dan aspal beton & 0,013 \\
2. Permukaan licin dan kedap air & 0,020 \\
3. Permukaan licin dan kokoh & 0,100 \\
4. Tanah rumput tipis dan gundul & 0,200 \\
permukaan sedikit kasar & \\
5. Padang rumput dan rerumputan & 0,400 \\
6. Hutan gundul & 0,600 \\
7. Hutan rimbun dan hutan gundul & 0,800 \\
dengan hampar rumput panjang & \\
sampai rapat & \\
\hline
\end{tabular}

Sumber : Tata cara Perencanaan Drainase Permukaan Jalan SNI-03-3424-1994

Tabel 4.6 Kecepatan Maksimum yang di ijinkan pada berbagai macam jenis saluran.

\begin{tabular}{lc}
\hline Jenis Bahan Saluran & $\begin{array}{c}\text { Kec. Aliran Air } \\
\text { Maksimum yang di } \\
\text { ijinkan (m³/detik) }\end{array}$ \\
\hline Pasir lempung & 0,45 \\
Lempung kepasiran & 0,50 \\
Lanau alluvial & 0,60 \\
Kerikil halus & 0,75 \\
Lempung kokoh & 0,75 \\
Lempung padat & 1,10 \\
Kerikil kasar & 1,20 \\
Batu-batu besar & 1,50 \\
Pasangan batu & 1,50 \\
Beton & 1,50 \\
\hline
\end{tabular}

Sumber : Tata cara Perencanaan Drainase Permukaan Jalan SNI-03-3424-1994

Maka didapat waktu konsentrasi ( TC) :

$\mathrm{t}$ aspal $=\{2 / 3 \times 3,28 \times 2,5 \times 0,013 / 0,02\} 0,167$

$$
=1,23
$$

$\mathrm{t}$ bahu $=\{2 / 3 \times 3,28 \times 0,5 \times 0,013 / 0,02\} 0,167$

$$
=0,94
$$

$\mathrm{t} \tan a h=\{2 / 3 \times 3,28 \times 50,0 \times 0,200 / 0,03\} 0,167$

$$
=3,00
$$

t1 $=5,17$ menit

$\mathrm{t} 2=1066 /(60 \times 1,5)=11,84$ menit

$\mathrm{Tc}=\mathrm{t} 1+\mathrm{t} 2=5,17+11,84=17,01$ menit

3. Menentukan Intensitas Curah Hujan Rencana Maksimum

Untuk menentukan intensitas curah hujan maksimum $(\mathrm{mm} / \mathrm{jam})$ digunakanya Kurva Basis, dengan cara memplotkan harga $\mathrm{Tc}=17,01$ menit, dikurva basis kemudian tarik garis atas sampai memotong intensitas hujan rencana, maka 
intensitas hujan maksimum dapat diketahui I maks $=136 \mathrm{~mm} / \mathrm{jam}$

4. Faktor Keamanan (Besarnya Koefisien Pengaliran C)

Faktor keamanan merupakan angka yang dikalikan dengan koefisien run off, bertujuan untuk supaya kinerja saluran drainase tidak melebihi kapasitasnya akibat luasnya daerah pengaliran, harga faktor keamanan ini disesuaikan dengan kondisi permukaan tanah dilokasi yang ditinjau. Dari Tabel 4.7 diketahui ketentuan nilai koefisien menurut SNI-03-3424-1994 sebagai berikut :

Tabel 4.7 Nilai koefisien pengaliran (C)

\begin{tabular}{lc}
\hline \multicolumn{1}{c}{$\begin{array}{c}\text { Kondisi Permukaan } \\
\text { Tanah }\end{array}$} & $\begin{array}{c}\text { Koefisien Pengaliran } \\
(\mathrm{C})^{*}\end{array}$ \\
\hline 1. Jalan beton dan jalan & $0,70-0,95$ \\
aspal & \\
2. Jalan kerikil dan jalan & $0,40-0,70$ \\
tanah & \\
3. Bahu jalan : & \\
- Tanah berbutir & $0,40-0,65$ \\
halus & $0,10-0,20$ \\
- Tanah berbutir & $0,70-0,85$ \\
kasar & $0,60-0,75$ \\
- Batuan masif keras & $0,70-0,95$ \\
- Batuan masif lunak & $0,60-0,70$ \\
4. Daerah perkotaan & $0,60-0,90$ \\
5. Daerah pinggir kota & $0,40-0,60$ \\
6. Daerah industri & $0,40-0,60$ \\
7. Pemukiman padat & $0,20-0,40$ \\
8. Pemukiman tidak & $0,45-0,60$ \\
padat & $0,70-0,80$ \\
9. Taman dan kebun & $0,75-0,90$ \\
10. Persawahan & \\
11. Perbukitan & \\
12. Pegunungan &
\end{tabular}

Sumber : Tata cara Perencanaan Drainase Permukaan Jalan SNI-03-3424-1994

Maka nilai koefisien pada lokasi yang ditinjau adalah sebagai berikut :

- L1 (Permukaan beraspal), Koefisien C, 0,70

- L2 (Bahu jalan tanah berbutir), Koefisien C, 0,40

- L3 (Bagian Luar jalan), Koefisien C, 0,60

Keterangan :

$\mathrm{L} 1=$ Ditetapkan dari as jalan sampai bagian tepi perkerasan

L2 = Ditetapkan dari tepi perkerasan sampai tepi bahu jalan

L3 = Tergantung daerah setempat
Koefisien diambil nilai yang terkecil dengan alasan lokasi yang ditinjau relatif datar dan tidak terlalu curam

5. Perhitungan Luas Daerah Pengaliran (Catchment Area)

Perhitungan daerah pengaliran diambil per meter panjang kemudian dikalikan dengan masingmasing segmen pengaliran, maka diperoleh :

- Jalan Aspal $(\mathrm{A} 1)=2,5=1066=2665 \mathrm{~m}^{2}$

- Bahu Jalan (A2)=0,5=1066=533 $\mathrm{m}^{2}$

- Bagian Luar Jalan (A3) $=50=1066=53300 \mathrm{~m}^{2}$

Daerah pengaliran terdiri dari beberapa tipe kondisi permukaan dengan nilai $\mathrm{C}$ yang berbeda.

6. Perhitungan Besarnya Debit Pengaliran (Q) Untuk menghitung debit aliran (Q) menggunakan metode rasional, sebagai berikut :

$$
\begin{aligned}
& \mathrm{A}(2665+533+53300)=0,056 \mathrm{~km}^{2} \\
& \mathrm{C}=0,603 \\
& \mathrm{I}=136 \mathrm{~mm} / \mathrm{jam} \\
& \mathrm{Q}=1 / 3,6 \times \mathrm{C} \times \mathrm{I} \times \mathrm{A}
\end{aligned}
$$

Dimana :

$\mathrm{Q}=$ Debit limpasan periode ulang $\mathrm{T}(\mathrm{m} 3 / \mathrm{det})$

$\mathrm{C}=$ Koefisien Limpasan

I $\quad=$ Intensitas Hujan $(\mathrm{mm} / \mathrm{jam})$

A $=$ Luas Chatchment Area $(\mathrm{km} 2)$

Maka :

$\mathrm{Q}=1 / 3,6 \times 0,603 \times 136 \times 0,056$

$=1,27 \mathrm{~m}^{3} /$ detik

7. Menentukan Luas Penampang Basah Saluran $(\mathrm{Fd})$

Saluran drainase dengan konstruksi pasangan batu kali, dengan kecepatan aliran maksimum yang di ijinkan $\mathrm{V}=1,50 \mathrm{~m}^{3} /$ detik, dari Tabel 4.6 , untuk menentukan penampang basah saluran drainase dapat dihitung menggunakan rumus sebagai berikut

$\mathrm{Fd}=\frac{\mathrm{Q}}{\mathrm{V}}$

$\mathrm{Q}=1,27 \mathrm{~m}^{3} /$ detik

$\mathrm{V}=1,50 \mathrm{~m}^{3} /$ detik

$\mathrm{Fd}=1,27 / 1,50=0,85 \mathrm{~m}^{2}$

8. Menentukan luas penampang ekonomis (Fe)

Konstruksi saluran drainase dari pasangan batu kali dengan bentuk persegi empat. 
Diketahui : $\mathbf{Q}=\mathbf{1 , 2 7} \mathrm{m}^{3} /$ detik

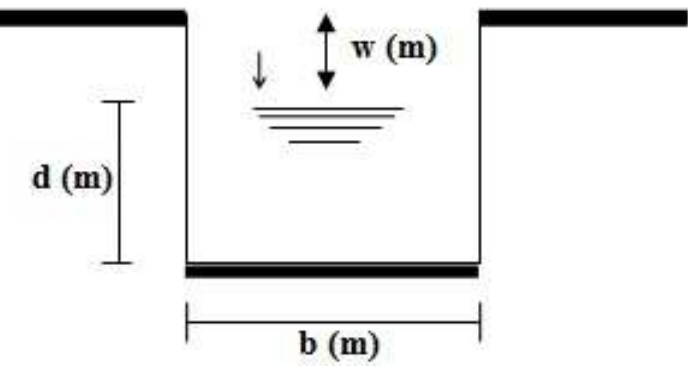

Gambar 4.2. Tipe saluran Drainase

9. Perhitungan dimensi saluran drainase Ketentuan :

$$
\begin{array}{ll}
\mathrm{b} & =2 \mathrm{~d} \\
\mathrm{Fe} & =\mathrm{Fd} \\
\mathrm{Fd} & =0,85 \\
\mathrm{bd} & =0,85 \\
2 \mathrm{~d} . \mathrm{d} & =0,85 \\
\mathrm{~d}^{2} & =0,85 / 2,0 \\
\mathrm{~b} & =2 \sqrt{ } 0,43 \\
\mathrm{~b} & =1,31 \mathrm{~m} \\
\mathrm{Fe} & =\mathrm{b} \cdot \mathrm{d} \\
0,85 & =1,31 \times \mathrm{x} \\
\mathrm{d} & =0,64 \mathrm{~m}
\end{array}
$$

$$
\begin{aligned}
& d=0,64 \mathrm{~m} \\
& b=1,31 \mathrm{~m} \\
& W=\sqrt{ } 0,5 \quad d=\sqrt{ } 0,5 \times 0,64=0,57 \mathrm{~m}
\end{aligned}
$$

\begin{tabular}{|c|c|c|c|c|}
\hline & Baik & & & \\
\hline Tipe Saluran & sekali & Baik & Sedang & Jelek \\
\hline Saluran tanah, lurus teratur. & 0,017 & 0,020 & 0,023 & 0,025 \\
\hline Saluran tanah yang dibuat dengan exavator. & 0,023 & 0,028 & 0,030 & 0,040 \\
\hline Saluran pada dinding batuan, lurus,teratur. & 0,020 & 0,030 & 0,033 & 0,035 \\
\hline Saluran pada dinding batuan, tdk lurus, tdk teratur. & 0,035 & 0,040 & 0,045 & 0,045 \\
\hline Saluran batuan yang diledakan, ada tumbuhan. & 0,025 & 0,030 & 0,035 & 0,040 \\
\hline Dasar saluran tanah, sisi saluran berbatu. & 0,028 & 0,030 & 0,033 & 0,035 \\
\hline Saluran lengkung dengan kecepatan aliran rendah. & 0,020 & 0,025 & 0,028 & 0,030 \\
\hline
\end{tabular}

Maka dimensi saluran yang diperlukan sesuai debit adalah :

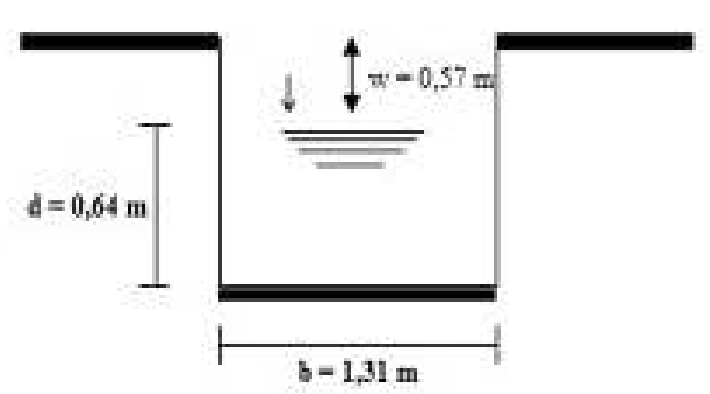

Gambar 4.3 : Dimensi saluran drainase ruas jalan $\mathrm{p} 1$. Sumber : Penyusun

10. Perhitungan Kemiringan saluran drainase Untuk menghitung kemiringan saluran, dapat dihitung dengan perhitungan sebagai berikut : Saluran dari konstruksi pasangan batu dengan kondisi baik sekali, dari : Tabel 4.8.
Tabel 4.8. Koefisien kekasaran manning.

Diketahui $\mathrm{n}=0,020$ (kekasaran maning) Tabel 4.8 Kecepatan air $=1,50 \mathrm{~m} /$ det. Tabel 4.6.

$$
\begin{aligned}
\mathrm{R} & =\frac{\mathrm{Fd}}{\mathrm{P}} \\
\mathrm{Fd} & =0,85 \\
\mathrm{P} & =\mathrm{b}+2 \mathrm{~d} \sqrt{1^{2}+1} \\
& =1,31+2 \times 0,64 \sqrt{1^{2}+1} \\
& =3,12
\end{aligned}
$$

$$
\mathbf{R}=\frac{0,85}{3,12}=0,272=0,27
$$

$$
\begin{aligned}
& \mathrm{i}=\left\{\frac{V \cdot n}{R \frac{2}{3}}\right\}^{2} \\
& \mathrm{i}=\left\{\frac{1,50 \times 0,020}{0,27 \times \frac{2}{3}}\right\}^{2} \\
& \mathrm{i}=0,028 \%
\end{aligned}
$$

Jadi kemiringan hasil perhitungan ( i ) $=0,028 \%$ 11. Kemiringan Tanah Lapangan

Diketahui : $\mathrm{t} 1=390$

$$
\begin{aligned}
& \mathrm{t} 2=345 \\
& \mathrm{~L}=1066 \mathrm{~m}
\end{aligned}
$$

$$
\begin{aligned}
\mathrm{i} \text { lapangan } & =\frac{\mathrm{t} 1-\mathrm{t} 2}{\mathrm{~L}}=\frac{390-345}{1066} \times 100 \% \\
& =0,042 \%
\end{aligned}
$$

Kemiringan lapangan ( $\mathrm{i})=0,042 \%$

i perhitungan $=0,028 \%<\mathrm{i}$ lapangan $=0,042 \%$ 
Berdasarkan hasil perhitungan kemiringan, diperoleh bahwa prosentase kemiringan lapangan lebih besar dari kemiringan ( i ) perhitungan. Maka memperlukan adanya saluran pematah arus

Tabel 4.9 Pematah arus hubungan kemiringan saluran samping jalan (i) dan jarak pematah arus.

\begin{tabular}{llllll}
\hline $\mathbf{i ~ ( \% )}$ & $6 \%$ & $7 \%$ & $8 \%$ & $9 \%$ & $10 \%$ \\
\hline $\mathbf{L ~ ( m ) ~}$ & $16 \mathrm{~m}$ & $10 \mathrm{~m}$ & $8 \mathrm{~m}$ & $7 \mathrm{~m}$ & $6 \mathrm{~m}$ \\
\hline
\end{tabular}

Sumber : Tata cara Perencanaan Drainase Permukaan Jalan SNI-03-3424-1994

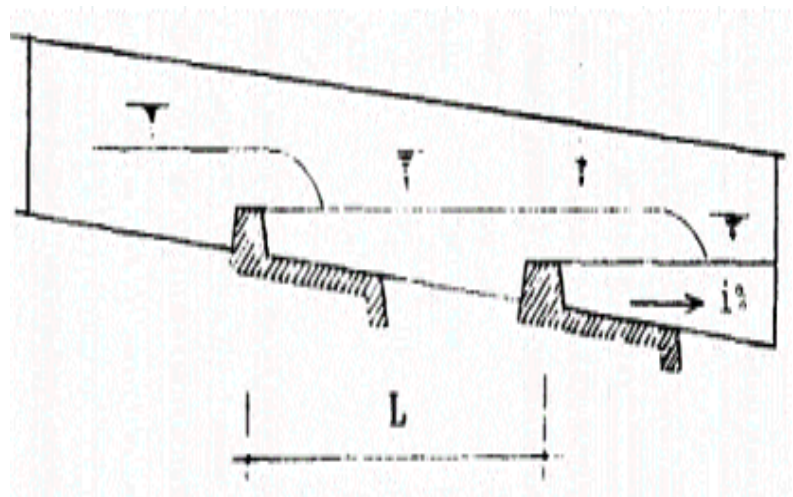

Gambar 4.4 :Pematah Arus. Sumber : Google.

12. Saluran Dengan bentuk Trapesium

Diketahui :

$$
\begin{array}{ll}
\mathrm{Q} & =1,34 \mathrm{~m}^{3} / \mathrm{det} \\
\mathrm{S} & =0,025(1: 4000) \\
\mathrm{n} & =0,020(\text { Kekasaran Manning) Tabel } 4.8
\end{array}
$$$$
\text { maka : }
$$$$
\mathrm{Q}=\mathrm{h}^{2} \sqrt{3} \frac{1}{n}\left(\frac{h}{2}\right)^{2 / 3} \mathrm{~S}^{1 / 2}
$$$$
1,27=\mathrm{h}^{2} \sqrt{3} \frac{1}{0,020}\left(\frac{h}{2}\right)^{2 / 3}\left(\frac{1}{4000}\right)^{1 / 2}
$$$$
1,27=h^{2} \frac{\sqrt{3}}{0,020} h^{2 / 3} / 1,5878 \frac{1}{63,245}
$$$$
1,27=\mathrm{h}^{(2+2 / 3)} \frac{\sqrt{3}}{2,008}
$$$$
1,27=\mathrm{h}^{8 / 3} \times 0,8625
$$$$
\frac{1,27}{0,8625}=\mathrm{h}^{8 / 3}
$$$$
1,47=\mathrm{h}^{8 / 3}
$$$$
1,47^{3 / 8}=\mathrm{h}
$$$$
\mathrm{h}=1,16 \mathrm{~m}
$$

\section{- Lebar dasar (b)}

$\mathrm{b}=\frac{2}{3} \mathrm{~h} \sqrt{3}$ $\begin{aligned} \mathrm{b} & =\frac{2}{3} 1,16 \sqrt{3} \\ \mathrm{~b} & =1,34 \mathrm{~m}\end{aligned}$

\section{- Tinggi jagaan (w)}

$$
\begin{aligned}
\mathrm{w} & =\sqrt{0,5 \mathrm{~h}} \\
\mathrm{w} & =\sqrt{0,5 \times 1,16} \\
\mathrm{w} & =0,76 \mathrm{~m}
\end{aligned}
$$

\section{- Bentuk penampang saluran Trapesium P1}

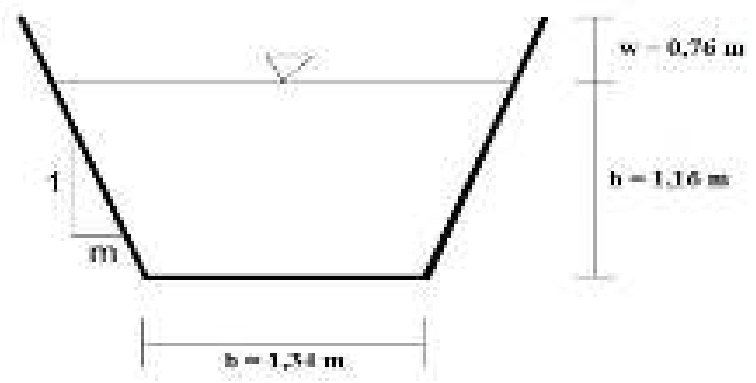

Gambar 4.5. : Saluran drainase bentuk trapesium

\section{f. Existing Saluran Drainase P2}

1. Daerah Pengaliran P2

Panjang saluran drainase $=950$ Meter

$\mathrm{L} 1=$ perkerasan jalan $=2,5 \quad$ Meter

$\mathrm{L} 2=$ bahu jalan $=0,5 \quad$ Meter

L3 $=$ bagian luar jalan $=50 \quad$ Meter

2. Waktu Konsentrasi

Waktu terpendek dibutuhkan untuk daerah tangkapan air dalam dalam menyalurkan aliran secara simultan (run off), setelah melewati titiktitik tertentu untuk mennentukan waktu konsentrasi ( Tc ) digunakan rumus sebagai berikut:

$$
\begin{aligned}
& \mathrm{Tc}=\mathrm{t} 1+\mathrm{t} 2 \\
& \mathrm{t} 1=(2 / 3 \times 3,28 \text { Lo } \mathrm{xd} / \sqrt{ } \mathrm{s}) \\
& \mathrm{t} 2=\mathrm{L} / 60 \mathrm{X} \\
& \text { Keterangan : } \\
& \mathrm{Tc}=\text { Waktu konsentrasi (menit) } \\
& \mathrm{t} 1 \quad=\text { Waktu intlet (menit) } \\
& \mathrm{t} 2=\text { Waktu aliran (menit) } \\
& \text { Lo = Jarak dari titik ke fasilitas drainase }(\mathrm{m}) \\
& \mathrm{nd}=\text { Koefisien hambatan } \\
& \mathrm{S}=\text { Kemiringan daerah pengaliran } \\
& \mathrm{V}=\text { Kecepatan rata-rata di saluran }(\mathrm{m} / \mathrm{dt}) \\
& \mathrm{L}=\text { Panjang saluran (m) } \\
& \text { Diketahui : } \\
& \mathrm{nd}=0,13 \text { (Tabel 4.5) } \\
& \mathrm{V}=1,50 \mathrm{~m}^{3} / \text { detik (Tabel 4.6) } \\
& \mathrm{L}=950 \mathrm{~m}
\end{aligned}
$$


$\mathrm{s}=$ Aspal $(0,02)$, bahu jalan $(0,02)$, tanah $(0,03)$

Lo $=$ Aspal $(5,0)$, bahu jalan $(1,0)$, tanah $(50,0)$

Maka didapat waktu konsentrasi ( TC) :

$$
\begin{aligned}
& \mathrm{t} \text { aspal }=\left\{\frac{2}{3} \times 3,28 \times 2,5 \times \frac{0,013}{0,02}\right\}^{0,167}=1,23 \\
& \mathrm{t} \text { bahu }=\left\{\frac{2}{3} \times 3,28 \times 0,5 \times \frac{0,013}{0,02}\right\}^{0,167}=0,94 \\
& \mathrm{t} \text { tanah }=\left\{\frac{2}{3} \times 3,28 \times 50,0 \times \frac{0,200}{0,03}\right\}^{0,167}=3,00 \\
& \mathrm{t} 1 \quad=5,17 \text { menit } \\
& \mathrm{t} 2 \quad=\frac{950}{60 \times 1,5}=10,6 \text { menit } \\
& \mathrm{Tc} \quad=\mathrm{t} 1+\mathrm{t} 2=5,17+10,6=15,77 \text { menit }
\end{aligned}
$$

3. Menentukan Intensitas Curah Hujan Maksimum

Untuk menentukan intensitas curah hujan maksimum ( $\mathrm{mm} / \mathrm{jam})$ dengan cara memplotkan harga $\mathrm{Tc}=15,77$ menit, dikurva baris kemudian tarik garis atas sampai memotong intensitas hujan rencana dan intensitas hujan maksimum dapat diketahui I maks $=140 \mathrm{~mm} / \mathrm{jam}$

4. Faktor Keamanan (Besarnya Koefisien Pengaliran C)

Faktor keamanan merupakan angka yang dikalikan dengan koefisien run off, bertujuan untuk supaya kinerja saluran drainase tidak melebihi kapasitasnya akibat luasnya daerah pengaliran, harga faktor keamanan ini disesuaikan dengan kondisi permukaan tanah dilokasi yang ditinjau. Dapat dilihat dari Tabel 4.7.

Maka nilai koefisien pada lokasi yang ditinjau adalah sebagai berikut :

L1 (Permukaan beraspal) Koefisien C $\quad 0,70$

L2 (Bahu jalan tanah berbutir) KoefisienC 0,40

L3 (Bagian Luar jalan) Koefisien C $\quad 0,60$

5. Perhitungan Luas Daerah Pengaliran (Catchment Area)

Perhitungan daerah pengaliran diambil per meter panjang kemudian dikalikan dengan masingmasing segmen pengaliran, maka diperoleh :

- Jalan Aspal (A1) $\quad 2,5 \quad 950 \quad 2375$ m$^{2}$

- Bahu Jalan (A2) $\quad 0,5 \quad 950 \quad 475$ m$^{2}$

- Bagian Luar Jalan (A3) $50 \quad 950 \quad 47500$ m²$^{2}$

Dearah pengaliran terdiri dari beberapa tipe kondisi permukaan dengan nilai $\mathrm{C}$ yang berbeda, maka $\mathrm{C}$ rata-rata dihitung dengan rumus :

$\mathrm{C}=(\mathrm{C} 1 . \mathrm{A} 1+\mathrm{C} 2 . \mathrm{A} 2+\mathrm{C} 3 . \mathrm{A} 3) /(\mathrm{A} 1+\mathrm{A} 2+\mathrm{A} 3)$

Maka :

$\mathrm{C}=(0,70 \times 2375+0,40 \times 475+0,60 \times$
6. Perhitungan Besarnya Debit Pengaliran (Q) Untuk menghitung debit ailran (Q) digunakan dengan rumus sebagai berikut :

A $(2375+475+47500)=0,050 \mathrm{~km}^{2}$

$$
\begin{aligned}
& \mathrm{C}=0,60 \\
& \mathrm{I}=140 \mathrm{~mm} / \mathrm{jam} \\
& \mathrm{Q}=1 / 3,6 \times \mathrm{C} \times \mathrm{I} \times \mathrm{A}
\end{aligned}
$$

Dimana :

Q = Debit limpasan periode ulang $\mathrm{T}(\mathrm{m} 3 / \mathrm{det})$

$\mathrm{C} \quad=$ Koefisien Limpasan

I $=$ Intensitas Hujan $(\mathrm{mm} / \mathrm{jam})$

A $\quad=$ Luas Chatchment Area $(\mathrm{km} 2)$

Maka :

$\mathrm{Q}=1 / 3,6 \times 0,60 \times 140 \times 0,050=1,17 \mathrm{~m}^{3} /$ detik

7. Menentukan Luas Penampang Basah Saluran(Fd)

Saluran drainase dengan konstruksi pasangan batu kali, dengan kecepatan aliran yang di ijinkan $\mathrm{V}=$ $1,50 \mathrm{~m}^{3} /$ detik, dari Tabel 4.6, untuk menentukan penampang basah saluran drainase dapat dihitung menggunakan rumus sebagai berikut :

$$
\begin{aligned}
& \mathrm{Fd}=\mathrm{Q} / \mathrm{V} \\
& \mathrm{Q}=1,17 \mathrm{~m}^{3} / \text { detik } \\
& \mathrm{V}=1,50 \mathrm{~m}^{3} / \text { detik } \\
& \mathrm{Fd}=1,17 / 1,50=0,78 \mathrm{~m}^{2}
\end{aligned}
$$

8. Menentukan luas penampang ekonomis (Fe)

Konstruksi saluran drainase dari pasangan batu kali dengan bentuk persegi empat. Diketahui : $\mathrm{Q}=1,17$ $\mathrm{m}^{3} /$ detik

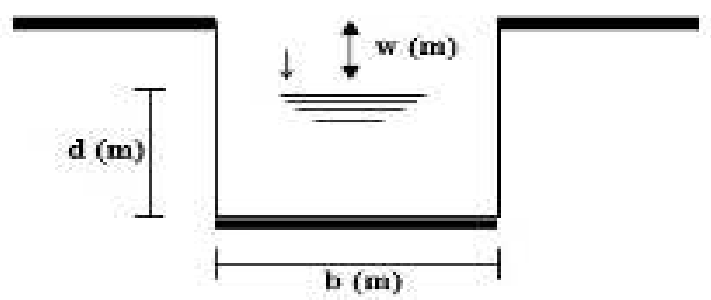

Gambar 4.6 : Dimensi saluran drainase ruas jalan

9. Perhitungan dimensi saluran drainase

$$
\begin{array}{ll}
\text { Ketentuan : } \\
\mathrm{Fe} & =\mathrm{Fd} \\
\mathrm{Fd} & =0,78 \\
\mathrm{bd} & =0,78 \\
2 \text { d.d } & =0,78 \\
\mathrm{~d}^{2} & =0,78 / 2,0 \\
\mathrm{~b} & =2 \sqrt{ } 0,39 \\
\mathrm{~b} & =1,25 \mathrm{~m} \\
\mathrm{Fe} & =\mathrm{b} \cdot \mathrm{d} \\
0,78 & =1,25 \times \mathrm{d}
\end{array}
$$




$$
\begin{aligned}
& \mathrm{d}=0,62 \mathrm{~m} \\
& \mathrm{~d}=0,62 \mathrm{~m} \\
& \mathrm{~b}=1,25 \mathrm{~m} \\
& \mathrm{~W}=\sqrt{0,5} \mathrm{~d}=\sqrt{0,5} \times 0,62=0,56 \mathrm{~m}
\end{aligned}
$$

Maka dimensi saluran yang diperlukan sesuai debit adalah:

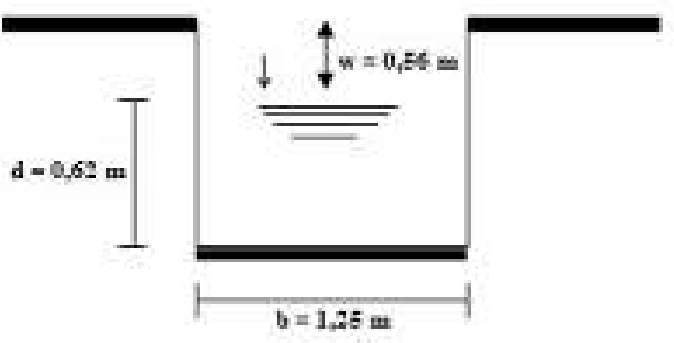

Gambar 4.7 : Dimensi saluran drainase ruas jalan p2.

Sumber : Penyusun

10. Perhitungan Kemiringan saluran drainase Untuk menghitung kemiringan saluran, dapat dihitung dengan perhitungan sebagai berikut :

Saluran dari konstruksi pasangan batu dengan kondisi cukup baik, dari Tabel 4.8.

Diketahui $\mathrm{n}=0,020$ (kekasaran maning) Tabel 4.8 ; Kecepatan air $=1,50 \mathrm{~m} /$ det. Tabel 4.6.

$$
\begin{aligned}
& \mathrm{R} \quad=\mathrm{Fd} / \mathrm{P} \\
& \mathrm{Fd} \quad=0,78 \\
& \mathrm{P} \quad=\mathrm{b}+2 \mathrm{~d} \sqrt{ }\left(\mathrm{n}^{\wedge} 2\right)+1 \\
& =1,25+2 \times 0,62 \sqrt{ }\left(1^{\wedge} 2+1\right)=3 \\
& \quad \mathrm{R}=0,78 / 3=0,26 \\
& \mathrm{i}=\{(\mathrm{V} . \mathrm{n}) /(\mathrm{R} 2 / 3)\} 2 \\
& \mathrm{i}=\{(1,50 \times 0,020) /(0,26 \times 2 / 3)\} 2 \\
& \mathrm{i}=0,027 \% \\
& \text { Jadi kemiringan hasil perhitungan }(\mathrm{i})=0,027 \% \\
& \quad \text { Kemiringan Tanah Lapangan } \\
& \quad \text { Diketahui : } \\
& \mathrm{t} 1=390 \\
& \mathrm{t} 2=345 \\
& \mathrm{~L}=950 \mathrm{~m}
\end{aligned}
$$

i lapangan $=(\mathrm{t} 1-\mathrm{t} 2) / \mathrm{L}=(390-345) / 950 \times 100 \%=$ $0,047 \%$

Kemiringan lapangan ( i ) $=0,047 \%$

i perhitungan $=0,027 \%<\mathrm{i}$ lapangan $=0,047 \%$

$\mathrm{t} 1=390$

11. Kemiringan Tanah Lapangan Diketahui :

$\mathrm{t} 2=345$

$\mathrm{L}=1066 \mathrm{~m}$

i lapangan $=(\mathrm{t} 1-\mathrm{t} 2) / \mathrm{L}=(390-345) / 1066 \times 100 \%=$ $0,042 \%$

Kemiringan lapangan ( i ) $=0,042 \%$

i perhitungan $=0,028 \%<\mathrm{i}$ lapangan $=0,042 \%$
Berdasarkan hasil perhitungan kemiringan, diperoleh bahwa prosentase kemiringan lapangan lebih besar dari kemiringan ( i ) perhitungan. Maka memperlukan adanya saluran pematah arus.Tabel 4.9

12. Saluran Dengan bentuk Trapesium Diketahui :

$$
\begin{aligned}
& \mathrm{Q} \quad=1,17 \mathrm{~m} 3 / \text { det } \\
& \mathrm{S} \quad=0,027 \% \\
& \mathrm{n} \quad=0,020(\text { Kekasaran Manning) Tabel } 4.8 \\
& \text { maka }: \\
& \mathrm{Q}=\mathrm{h} 2 \sqrt{3} 1 / \mathrm{h}(\mathrm{h} / 2) 2 / 3 \mathrm{~S} 1 / 2 \\
& 1,17=\mathrm{h} 2 \sqrt{3} 1 / 0,020(\mathrm{~h} / 2) 2 / 3(27 / 1000) 1 / 2 \\
& 0,68=\mathrm{h} 8 / 3 \\
& 0,683 / 8=\mathrm{h} \\
& \mathrm{h}=0,86 \mathrm{~m} \\
& \quad \text { Lebar dasar }(\mathrm{b}) \\
& \mathrm{b}=2 / 3 \mathrm{~h} \sqrt{3} \\
& \mathrm{~b}=2 / 30,86 \sqrt{3} \\
& \mathrm{~b}=0,99 \mathrm{~m} \\
& \quad \text { Tinggi jagaan }(\mathrm{w}) \\
& \mathrm{W}=\sqrt{ }(0,5 \mathrm{~h}) \\
& \mathrm{W}=\sqrt{(}(0,5 \mathrm{x} 0,86) \\
& \mathrm{W}=0,66 \mathrm{~m}
\end{aligned}
$$

Bentuk penampang saluran Trapesium P2

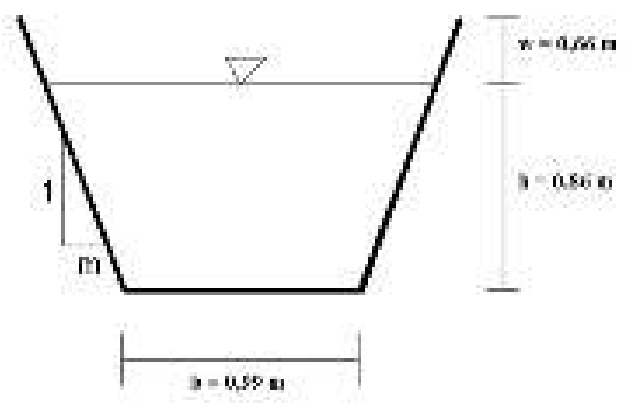

Gambar 4.8. : Saluran drainase bentuk trapesium

\section{g. Existing Saluran Drainase P3}

Daerah Pengaliran P3

Panjang saluran drainase 1184 Meter

$\mathrm{L} 1=$ perkerasan jalan $\quad 2,5$ meter

L2 = bahu jalan 0,5 Meter

L3 = bagian luar jalan 50 Meter

1. Waktu Konsentrasi

Waktu terpendek dibutuhkan untuk daerah tangkapan air dalam dalam menyalurkan aliran secara simultan (run off), setelah melewati titiktitik tertentu untuk mennentukan waktu konsentrasi ( Tc ) digunakan rumus sebagai berikut:

$$
\begin{aligned}
& \mathrm{Tc}=\mathrm{t} 1+\mathrm{t} 2 \\
& \mathrm{t} 1=\left(2 / 3 \times 3,28 \text { Lo } \times \mathrm{nd} / \sqrt{ }_{\mathrm{s}}\right)
\end{aligned}
$$




$$
\mathrm{t} 2=\mathrm{L} / 60 \times \mathrm{V}
$$

Keterangan :

$\mathrm{Tc}=$ Waktu konsentrasi (menit)

t1 = Waktu intlet (menit)

t2 = Waktu aliran (menit)

Lo $=$ Jarak dari titik ke fasilitas drainase (m)

nd $=$ Koefisien hambatan

$\mathrm{s}=$ Kemiringan daerah pengaliran

$\mathrm{V}=$ Kecepatan rata-rata di saluran $(\mathrm{m} / \mathrm{dt})$

$\mathrm{L}$ = Panjang saluran $(\mathrm{m})$

Diketahui :

nd $=0,13($ Tabel 4.5)

$\mathrm{V}=1,50 \mathrm{~m}^{3} / \operatorname{detik}$ (Tabel 4.6)

$\mathrm{L}=1184 \mathrm{~m}$

$\mathrm{s}=$ Aspal $(0,02)$, bahu jalan $(0,02)$, tanah $(0,03)$.

Lo $=$ Aspal $(5,0)$, bahu jalan $(1,0)$, tanah $(50,0)$.

Maka didapat waktu konsentrasi ( TC) :

$\mathrm{t}$ aspal $=\{2 / 3 \times 3,28 \times 2,5 \times 0,013 / 0,02\} 0,167=$ 1,23

$\mathrm{t}$ bahu $=\{2 / 3 \times 3,28 \times 0,5 \times 0,013 / 0,02\} 0,167=0,94$

$\mathrm{t} \tan a h=\{2 / 3 \times 3,28 \times 50,0 \times 0,200 / 0,03\} 0,167=$ 3,00

$\mathrm{t} 1=5,17$ menit

$\mathrm{t} 2=1184 /(60 \times 1,5)=13,15$ menit

Tc $=\mathrm{t} 1+\mathrm{t} 2=5,17+13,15=18,32$ menit

2. Menentukan Intensitas Curah Hujan Maksimum

Untuk menentukan intensitas curah hujan maksimum (mm/jam) dengan cara memplotkan harga $\mathrm{Tc}=18,32$ menit, dikurva baris kemudian tarik garis atas sampai memotong intensitas hujan rencana kemudian intensitas hujan maksimum dapat diketahui I maks $=130 \mathrm{~mm} / \mathrm{jam}$

3. Faktor Keamanan (Besarnya Koefisien Pengaliran C)

Faktor keamanan merupakan angka yang dikalikan dengan koefisien run off, bertujuan untuk supaya kinerja saluran drainase tidak melebihi kapasitasnya akibat luasnya daerah pengaliran, harga faktor keamanan ini disesuaikan dengan kondisi permukaan tanah dilokasi yang ditinjau. Dapat dilihat dari Tabel 4.7.

Maka nilai koefisien pada lokasi yang ditinjau adalah sebagai berikut :

L1 (Permukaan beraspal) Koefisien C 0,70

L2 (Bahu jalan tanah berbutir) Koefisien C 0,40

L3 (Bagian Luar jalan) Koefisien C 0,60

4. Perhitungan Luas Daerah Pengaliran (Catchment Area)

Perhitungan daerah pengaliran diambil per meter panjang kemudian dikalikan dengan masingmasing segmen pengaliran, maka diperoleh :
Jalan Aspal (A1)
2,5
1184
$2960 \mathrm{~m}^{2}$
Bahu Jalan (A2)

Bagian Luar Jalan (A3) 50

$118459200 \mathrm{~m}^{2}$

Dearah pengaliran terdiri dari beberapa tipe kondisi permukaan dengan nilai $\mathrm{C}$ yang berbeda, maka $\mathrm{C}$ rata-rata dihitung dengan rumus :

$\mathrm{C}=(\mathrm{C} 1 . \mathrm{A} 1+\mathrm{C} 2 . \mathrm{A} 2+\mathrm{C} 3 . \mathrm{A} 3) /(\mathrm{A} 1+\mathrm{A} 2+\mathrm{A} 3)$

Maka :

$\mathrm{C}=(0,70 \times 2960+0,40 \times 592+0,60 \times$ $59200) /(2960+592+59200)=0,602$

5. Perhitungan Besarnya Debit Pengaliran (Q) Untuk menghitung debit ailran (Q) digunakan dengan rumus sebagai berikut :

A $(2960+592+59200)=0,063 \mathrm{~km}^{2}$

$\mathrm{C}=0,602$

$\mathrm{I}=130 \mathrm{~mm} / \mathrm{jam}$

$\mathrm{Q}=1 / 3,6 \times \mathrm{C} \times \mathrm{I} \times \mathrm{A}$

Dimana :

Qt = Debit limpasan periode ulang $\mathrm{T}$ (m3/det)

C $=$ Koefisien Limpasan

I $=$ Intensitas Hujan ( $\mathrm{mm} / \mathrm{jam})$

A $=$ Luas Chatchment Area $(\mathrm{km} 2)$

Maka :

$\mathrm{Q}=1 / 3,6 \times 0,602 \times 130 \times 0,063$

$=1,37 \mathrm{~m}^{3} /$ detik

6. Menentukan Luas Penampang Basah Saluran $(\mathrm{Fd})$

Saluran drainase dengan konstruksi pasangan batu kali, dengan kecepatan aliran yang di ijinkan $\mathrm{V}=$ 1,50 $\mathrm{m}^{3} /$ detik, dari Tabel 4.6, untuk menentukan penampang basah saluran drainase dapat dihitung menggunakan rumus sebagai berikut :

$\mathrm{Fd}=\mathrm{Q} / \mathrm{V}$

$\mathrm{Q}=1,37 \mathrm{~m}^{3} /$ detik

$\mathrm{V}=1,50 \mathrm{~m}^{3} /$ detik

$\mathrm{Fd}=1,37 / 1,50=0,89 \mathrm{~m}^{2}$

7. Menentukan luas penampang ekonomis (Fe)

Konstruksi saluran drainase dari pasangan batu kali dengan bentuk persegi empat.

Diketahui : $\mathrm{Q}=1,37 \mathrm{~m}^{3} /$ detik.

8. Perhitungan dimensi saluran drainase Ketentuan :

$\begin{array}{ll}\mathrm{b} & =2 \mathrm{~d} \\ \mathrm{Fe} & =\mathrm{Fd} \\ \mathrm{Fd} & =0,89 \\ \mathrm{bd} & =0,89 \\ 2 \mathrm{~d} \cdot \mathrm{d} & =0,89 \\ \mathrm{~d}^{2} & =0,89 / 2,0 \\ \mathrm{~b} & =2 \sqrt{ } 0,45 \\ \mathrm{~b} & =1,34 \mathrm{~m} \\ \mathrm{Fe} & =\mathrm{b} \cdot \mathrm{d} \\ 0,89 & =1,34 \mathrm{xd} \\ \mathrm{d} & =0,66 \mathrm{~m} \\ \mathrm{~d}=0,66 \mathrm{~m} & \\ \mathrm{~b}=1,34 \mathrm{~m}\end{array}$




$$
W=\sqrt{ } 0,5 d=\sqrt{ } 0,5 \times 0,66=0,57 m
$$

Maka dimensi saluran yang diperlukan sesuai debit adalah :
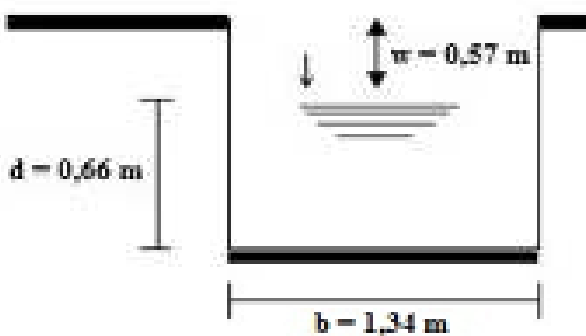

Gumbar 4.9 :Dimensi siluram drainilse ruals jalan p3.

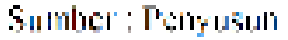

9. Perhitumyan Kemiringan saluran drainsse

Linluk menghilung kemiringen saluaran, dapal

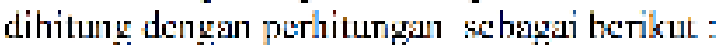

Saluran dari konstrulsi pasangan batu deneat kondisi cukup lsaik, dari Tahel 4.X.

Dikelahui $n=0,020$ (kekasarun maning) Tabel 4.8 . ; Kecepatan air $=1,50$ midet. Tabel 4.6 .

$$
\begin{aligned}
\mathrm{K} & =\mathrm{Fd}: \mathrm{P} \\
\Gamma \mathrm{d} & =0.89 \\
\mathrm{P} & =\mathrm{b}+2 \mathrm{~d} \sqrt{ }\left(\mathrm{n}^{\wedge} 2\right)+1 \\
& =1,34+2 \times 0,66 \sqrt{ }\left(1^{\wedge} 2+1\right) \\
& =3,20
\end{aligned}
$$

$\mathrm{R}=0,89 / 3,20=0,28$

$\mathrm{i}=\{(\mathrm{V} . \mathrm{n}) /(\mathrm{R} 2 / 3)\} 2$

$\mathrm{i}=\{(1,50 \times 0,020) /(0,28 \times 2 / 3)\} 2$

$\mathrm{i}=0,025 \%$

Jadi kemiringan hasil perhitungan ( $i$ ) $=0,025 \%$

10. Kemiringan Tanah Lapangan

Diketahui :

$\mathrm{t} 1=390$

$\mathrm{t} 2=345$

$\mathrm{L}=1184 \mathrm{~m}$

$\mathrm{i}$ lapangan $=(\mathrm{t} 1-\mathrm{t} 2) / \mathrm{L}=(390-345) / 1184 \times 100 \%=$ $0,038 \%$

Kemiringan lapangan ( i ) $=0,038 \%$

i perhitungan $=0,025 \%<\mathrm{i}$ lapangan $=0,038 \%$

Berdasarkan hasil perhitungan kemiringan, diperoleh bahwa prosentase kemiringan lapangan lebih besar dari kemiringan ( i ) perhitungan. Maka perlu adanya saluran pematah arus. Tabel 4.9.

11. Saluran Dengan bentuk Trapesium

Diketahui :

$$
\begin{array}{ll}
\mathrm{Q} & =1,37 \mathrm{~m} 3 / \mathrm{det} \\
\mathrm{S} & =0,025 \% \\
\mathrm{n} & =0,020(\text { Kekasaran Manning) Tabel } 4.8 \\
\text { maka : } &
\end{array}
$$
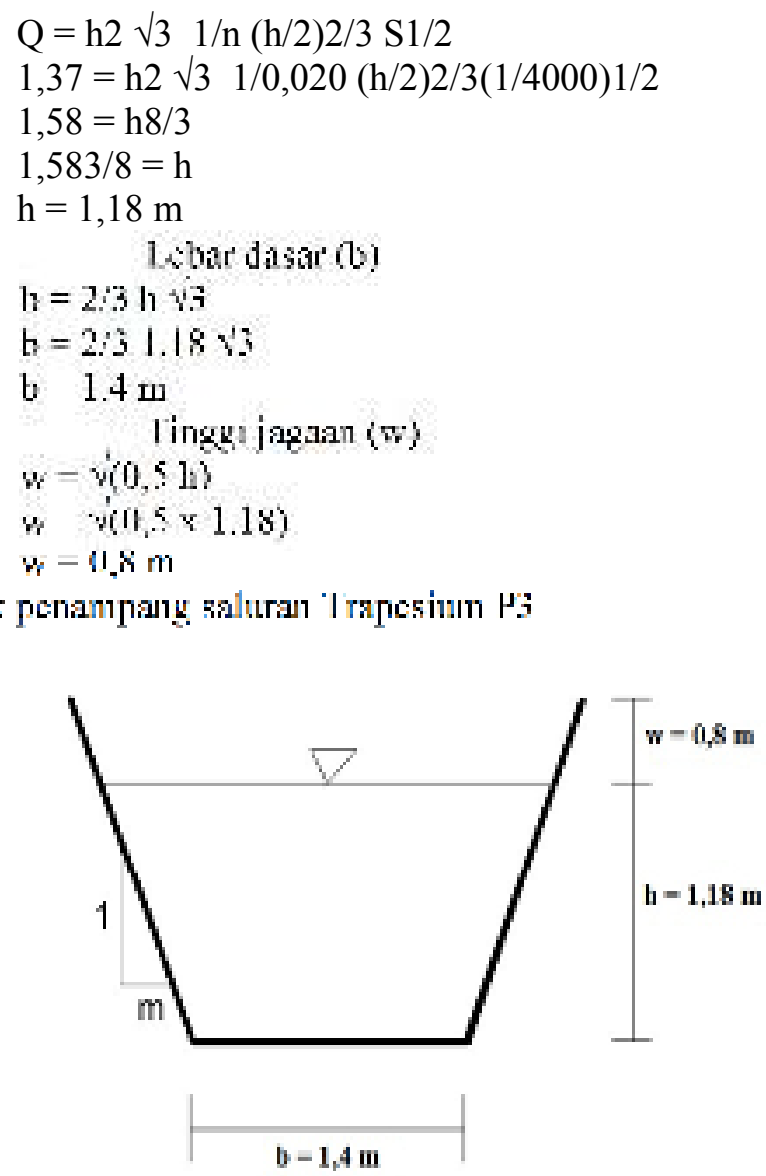

Gambar 4.10.Saluran drainase bentuk trapesium P3

\section{h. Sumur Resapan}

Untuk menanggulangi genangan air dan apabila saluran drainase tidak memungkinkan untuk dibangun karena sempitnya lahan di Jalan Aria Wiratanudatar Cianjur, alternatif lain dapat dilakukan dengan membuat sumur resapan di area milik pribadi di sepanjang ruas jalan yang ditinjau, untuk menghitung kedalaman optimum dapat dihitung dengan langkah-langkah sebagai berikut, (sunjoto, 1988) :

1. Sumur Resapan di P1

1. Debit banjir rancangan $=1,27 \mathrm{~m} 3 /$ det

2. Daya tampung saluran drainase existing :

$$
\begin{aligned}
\pi & =0,02(\text { Kekasaran maning) } \\
\mathrm{S} & =0,00042 \text { (Kemiringan saluran) } \\
\mathrm{Q} & =\mathrm{V} \times \mathrm{A} \\
& =1 / \pi \times \mathrm{R} 2 / 3 \times \mathrm{S} 1 / 2 \times \mathrm{A} \\
\mathrm{A} & =\mathrm{d} \times \mathrm{b}=0,64 \times 1,31=0,8 \mathrm{~m} 2 \\
\mathrm{P} & =1,31+2(0,64)=2,6 \mathrm{~m} \\
\mathrm{R} & =\mathrm{A} / \mathrm{P}=0,8 / 2,6=0,30 \\
= & 1 / 0,02(0,30) 2 / 3(0,00042) 1 / 2(0,8) \\
= & 0,367 \mathrm{~m} 3 / \text { det }
\end{aligned}
$$

3. Debit yang harus ditampung Sumur resapan 
Qsr $=1,27-0,367=0,9 \mathrm{~m} 3 /$ det

4. Perencanaan dimensi sumur resapan

$$
\begin{aligned}
& \mathrm{L}=1066 \mathrm{~m} \\
& \mathrm{~A}=56498 \mathrm{~m} 2 \\
& \mathrm{~K}=2,66 \times 10-4 \mathrm{~m} / \text { det } \\
& \mathrm{T}=2 \mathrm{jam}=120 \mathrm{menit} \\
& \mathrm{D}=1 \mathrm{~m} \\
& \mathrm{~F}=5,5 \mathrm{r}=5,5 \times 0,5=2,75 \mathrm{~m} \\
& \mathrm{H}=3 \mathrm{~m} \\
& \mathrm{Q}=\mathrm{H} . \mathrm{F} . \mathrm{K}=3 \times 2,75 \times 2,66 \times 10-4 \\
& \mathrm{Q}=2,1945 \times 10-3 \mathrm{~m} 3 / \mathrm{det}
\end{aligned}
$$

Untuk menampung 0,9 m3/det maka diperlukannya jumlah sumur resapan $=0,9 / 2,1945 \times 10-3=410$ buah

Satu buah sumur mewakili $=56498 / 410=137,8 \mathrm{~m} 2$

2. Sumur Resapan di P2

1.Debit banjir rancangan $=1,17 \mathrm{~m} 3 / \mathrm{det}$

2.Daya tampung saluran drainase existing :

$$
\begin{aligned}
& \pi=0,02 \text { (Kekasaran maning) } \\
& \mathrm{S}=0,00027 \text { (Kemiringan saluran) } \\
& \mathrm{Q}=\mathrm{V} \times \mathrm{A} \\
& =1 / \pi \times \mathrm{R} 2 / 3 \times \mathrm{S} 1 / 2 \times \mathrm{A} \\
& \mathrm{A}=\mathrm{d} \times \mathrm{b}=0,62 \times 1,25=0,8 \\
& \mathrm{P}=1,25+2(0,62)=2,5 \\
& \mathrm{R}=\mathrm{A} / \mathrm{P}=0,8 / 2,5=0,32 \\
& =1 / 0,02(0,32) 2 / 3(0,00027) 1 / 2(0,8) \\
& =0,30 \mathrm{~m} 3 / \mathrm{det}
\end{aligned}
$$

3.Debit yang harus ditampung Sumur resapan

Qsr $=1,17-0,30=0,87 \mathrm{~m} 3 /$ det

4.Perencanaan dimensi sumur resapan

$$
\begin{aligned}
& \mathrm{L}=950 \mathrm{~m} \\
& \mathrm{~A}=50350 \mathrm{~m} 2 \\
& \mathrm{~K}=2,6 \times 10-4 \mathrm{~m} / \text { det } \\
& \mathrm{Td}=2 \mathrm{jam}=120 \text { menit } \\
& \mathrm{D}=1 \mathrm{~m} \\
& \mathrm{~F}=5,5 \mathrm{r}=5,5 \times 0,5=2,75 \\
& \mathrm{H}=3 \mathrm{~m} \\
& \mathrm{Q}=\mathrm{H} \cdot \mathrm{F} . \mathrm{K}=3 \times 2,75 \times 2,6 \times 10-4 \\
& \mathrm{Q}=2,14 \times 10-3 \mathrm{~m} 3 / \text { det }
\end{aligned}
$$

Untuk menampung $0,87 \mathrm{~m} 3 /$ det maka diperlukannya jumlah sumur resapan $=0,87 / 2,14 \mathrm{x}$ 10-3 = 406 buah Satu buah sumur mewakili $=50350 / 406=124 \mathrm{~m} 2$

3. Sumur Resapan di P3

1. Debit banjir rancangan $=1,37 \mathrm{~m} 3 / \mathrm{det}$

2.Daya tampung saluran drainase existing :

$$
\begin{aligned}
\pi & =0,02(\text { Kekasaran maning) } \\
\mathrm{S} & =0,00025(\text { Kemiringan saluran) } \\
\mathrm{Q} & =\mathrm{V} \times \mathrm{A} \\
& =1 / \pi \times \mathrm{R} 2 / 3 \times \mathrm{S} 1 / 2 \times \mathrm{A} \\
\mathrm{A} & =\mathrm{d} \times \mathrm{b}=0,66 \times 1,34=0,9 \\
\mathrm{P} & =1,34+2(0,66)=2,7 \\
\mathrm{R} & =\mathrm{A} / \mathrm{P}=0,9 / 2,7=0,33 \\
& =1 / 0,02(0,33) 2 / 3(0,00025) 1 / 2(0,9)
\end{aligned}
$$

$=0,34 \mathrm{~m} 3 / \mathrm{det}$

3.Debit yang harus ditampung Sumur resapan Qsr $=1,37-0,34=1,03 \mathrm{~m} 3 /$ det

4.Perencanaan dimensi sumur resapan

$$
\begin{aligned}
& \mathrm{L}=1184 \mathrm{~m} \\
& \mathrm{~A}=62752 \mathrm{~m} 2 \\
& \mathrm{~K}=2,76 \times 10-4 \mathrm{~m} / \mathrm{det} \\
& \mathrm{Td}=2 \mathrm{jam}=120 \text { menit } \\
& \mathrm{D}=1 \mathrm{~m} \\
& \mathrm{~F}=5,5 \mathrm{r}=5,5 \times 0,5=2,75 \\
& \mathrm{H}=3 \\
& \mathrm{Q}=\mathrm{H} . \mathrm{F} . \mathrm{K}=3 \times 2,75 \times 2,76 \times 10-4 \\
& \mathrm{Q}=2,3 \times 10-3 \mathrm{~m} 3 / \text { det }
\end{aligned}
$$

Untuk menampung 1,03 $\mathrm{m} 3 /$ det maka diperlukannya jumlah sumur resapan $=1,03 / 2,3 \mathrm{x}$ 10-3 = 447 buah

Satu buah sumur mewakili $=62752 / 447=140 \mathrm{~m} 2$

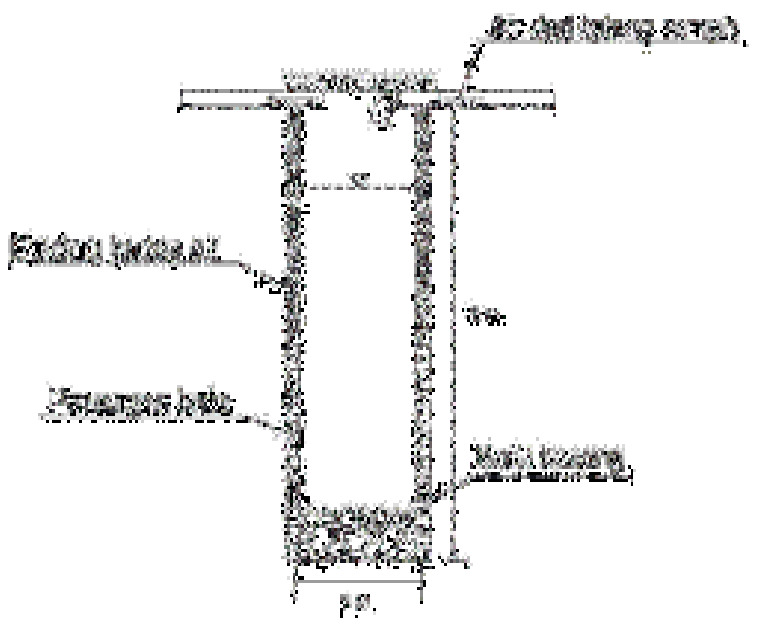

Gambar 4.11 Detail Sumur Resapan. Sumber : Penyusun

\section{KESIMPULAN}

Perlu adanya analisa dalam penelitian ini dengan tujuan untuk memaparkan hasil analisa studi dengan permasalahan yang ada dilapangan.

Terdapat beberapa faktor yang akan di evaluasi, antara lain :

1. Kondisi Existing Saluran Drainase

Dimensi saluran yang ada dilapangan dengan ukuran 70 x $20 \mathrm{~cm}$. Sedangkan menurut hasil perhitungan eksiting drainase diperbesar menjadi, $\mathrm{P} 1=1,31 \times 1,21 \mathrm{~m}, \mathrm{P} 2=1,25 \times 1,18$ $\mathrm{m}, \mathrm{P} 3=1,34 \times 1,23 \mathrm{~m}$.

Kondisi saluran drainase pada ruas jalan P1, P2, dan P3 mengalami hambatan dalam kinerja pengaliran air antara lain disebabkan oleh menyempitnya luas penampang saluran akibat 
sedimentasi dan sampah, instalasi pipa PDAM dan instalasi kabel telekomunikasi.

Lahan yang terbatas untuk memperbesar dimensi saluran drainase, tetapi terdapat ada beberapa lokasi yang memungkinkan untuk memperbesar dimensi saluran.

Jarangnya pemeliharaan secara berkala dan tentunya biaya yang dikeluarkan cukup besar.

2. Sampah dan Lumpur

Sampah dan lumpur menjadi prioritas utama dalam penyebab terjadinya banjir maupun genangan air, tanpa adanya ketegasan oleh pemerintah mengenai peng alokasian sampah, dengan hasil survei lapangan penyusun mengetahui kebiasaan masnyarakat membuang sampah ke saluran drainase dengan cara wawancara langsung, meskipun sampah yang dibuang ke saluran relatif kecil namun apabila dikalikan dengan jumlah pembuang sampah yang membuang ke saluran drainase tersebut, maka sampah yang akan tertahan di saluran apabila tersumbat menjadi banyak, maka dari itu pentingnya kesadaran dari masyarakat tersendiri.

3. Intensitas Curah Hujan

Penyebab terjadinya pelimpasan air di atas permukaan jalan apabila di tinjau dari intensitas curah hujan adalah sebagai berikut :

Berdasarkan luas daerah pengaliran (Catchment Area), diketahui besarnya debit pengaliran seperti pada ruas jalan $\mathrm{P} 1=1,27$ $\mathrm{m} 3 /$ det, $\mathrm{P} 2=1,17 \mathrm{~m} 3 /$ det, $\mathrm{P} 3=1,37 \mathrm{~m} 3 / \mathrm{det}$, dengan curah hujan yang tidak stabil, diagram curah hujan terlampir sebagai berikut :

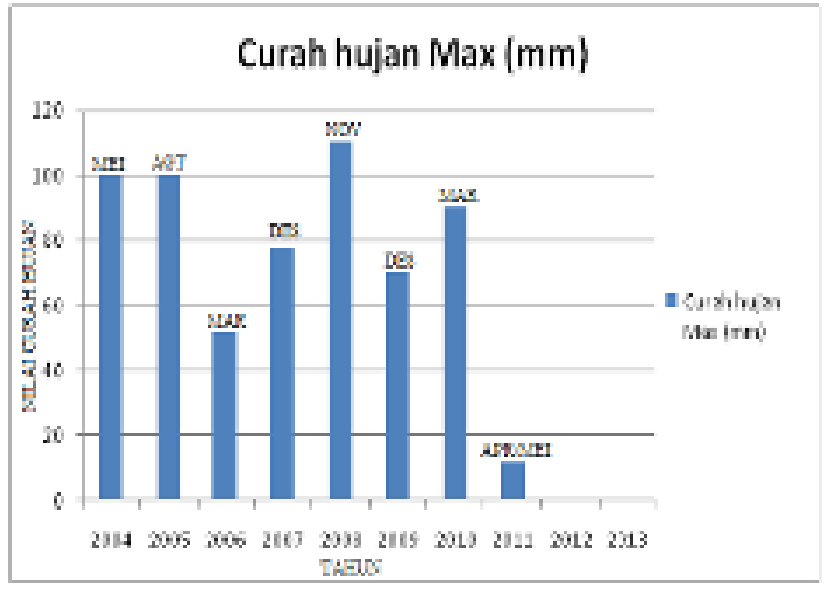

Gambar 4.12 Diagram Curah Hujan. Sumber : Penyusun

Menurut hasil perhitungan, besarnya debit pengaliran $(\mathrm{Q})$, pada masing-masing ruas jalan $\mathrm{P} 1$, $\mathrm{P} 2$, dan P3, maka dapat diketahui dimensi saluran drainase yang diperlukan, namun disesuaikan dengan luasnya daerah pengaliran.

4. Solusi Untuk Mengurangi Besarnya Debit Aliran.

Ada beberapa solusi yang harus dicapai untuk mengurangi besarnya debit aliran yaitu :

Memperdalam kedalaman saluran drainase dengan cara pengerukan sampah-sampah dan sedimentasi, agar tidak menghambat kinerja drainase.

Dapat juga meninggikan permukaan perkerasan, dan penambahan intlet.

Untuk dapat memperlancar proses pengaliran, dapat dengan memperlebar dimensi dan memperdalam saluran drainase atau merencanakan dimensi saluran drainase yang sesuai dengan perhitungan, berikut dimensi saluran drainase baru

a. Saluran di ruas jalan P1.

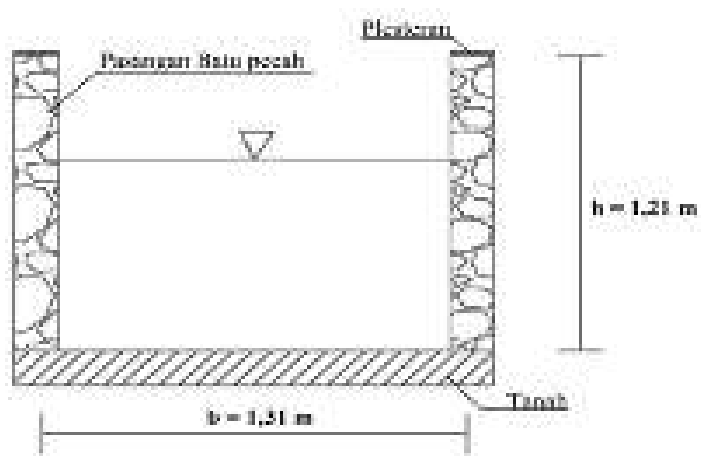

Gambar 5.1. Saluran di ruas jalan P1.

b. Saluran di ruas jalan P2.

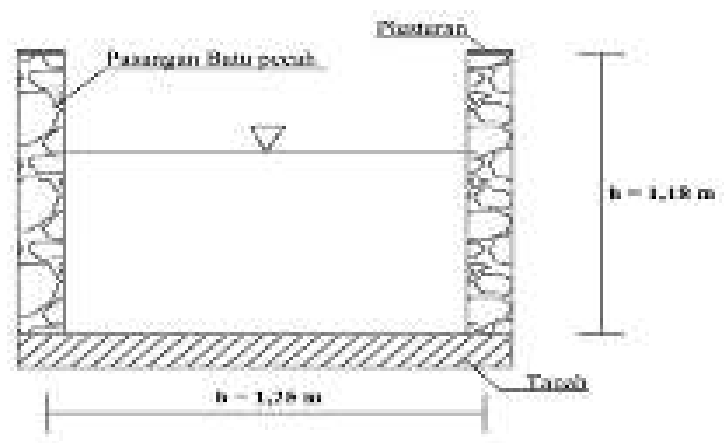

Gambar 5.1. Saluran di ruas jalan P2

c. Saluran di ruas jalan P3. 


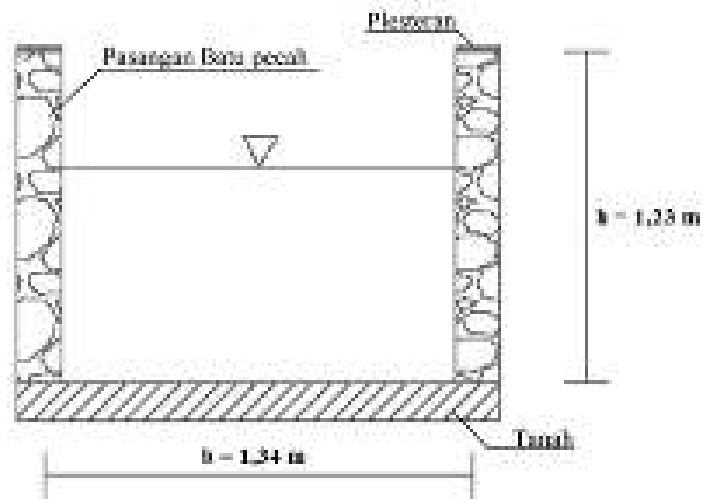

Gambar 5.1. Saluran di ruas jalan P3

Aplikasi yang dipakai dalam penelitian ini untuk tercapainya efisiensi dalam pengerjaan saluran drainase apabila diterapkan dilapangan yakni memperdalam tinggi (h) saluran existing yang ada dilokasi yang ditinjau, namun lebar (b) tidak berubah, hal tersebut sulitnya melakukan pembebasan lahan dilapangan dikarenakan banyak bangunan-bangunan yang berdiri di atas dan atau disamping saluran drainase.

\section{DAFTAR PUSTAKA}

Suripin. 2004. Sistem Drainase Perkotaan yang berkelanjutan.

SNI-03-3424-1994, Tata cara Perencanaan Drainase Permukaan Jalan.

Diyanto Wirastowo. 2007. Tugas akhir, Unika Soegijapranata : Semarang.

Documents.tips, rancangan-drainase, http://documents.tips/documents/bab-1rancangan-drainase/ diakses 26 juli 2019

Lorens kambuaya, 2014, bentuk-dan-dimensisaluran-terbuka, http://lorenskambuaya.blogspot.co.id/20 14/05/ diakses 26 juli 2019

Arya persada, sistem-drainase-jalan, www.Aryapersada.com/sistem-drainasejalan/ diakses 26 juli 2019

Darmadi, 2014, Pedoman-perencanaandrainase-jalan.pdf, www.wordpress.com/ Pedoman-perencanaan-drainasejalan.pdf/ diakses 26 juli 2019 